\title{
Free time for seniors as an activating action
}

\author{
Dorota Rynkowska
}

Jarosław Kinal

Institute of Sociology, University of Rzeszow

\begin{abstract}
Modern civilization is primarily a fast pace of life, a number of changes in human life, the need to face many tasks and Obligations. Free time in contemporary European democratic societies is one of More important noneconomic indicators describing the quality of life of citizens (Flora, Noll 1999). Intense activity leads to fatigue, fatigue and sometimes discouragement This to effectively and perform their duties properly and meet the everyday demands, the end is planning zne leisure, entertainment, or leisure time. The sphere of free time fulfills important roles in human life, translated into the quality of the individual and of age Society. This applies to all ages, especially seniors who ruined s are a special category, both adrestatów and Recipients of free time. The demographic processes that we can currently observe in Europe, a Also in many countries around the world, they lead to an increase in number and the proportion of older people in społeczeńst knows. Seniors represent a diverse social group in terms of cultural features, social status, health problems, economic Social. Aging in roses NYM rate, thus roses $A D$ are their needs and forms of activity and lifestyles, Tore correlate with $\mathrm{k}$ Date of free timeThe aim of this article is an attempt to present the seniors free time, its functions, types and forms in the context of the activities undertaken by them aktywnoś you.
\end{abstract}

Keywords: free time, old age, senior, activity, activation

\section{Introduction}

\section{Old age and activity}

Old age is a natural phenomenon, which is a very individual process. The limits of old age are very fluid and the process of aging goes through stages. Aging is continuous and irreversible. The elderly are not only from biological or physiological, but also stand out against the background of society different visible features, behavior, etc. The aging as a natural process of development, is one of the stages of life of a man who can neither be withdrawn nor reversible, what more is the period $\mathrm{d}$ of the tell everyone wants to live. Aging is of great importance in the individual, social, family and ekonomicznym.Starość as the last step in ns until recently was post rzegany gro wnie as the period $p$ rowadzacy degradation of health perception of somatic complaints, failure, progressive dependency on environment, isolation, and lack of acceptance alone Kindness. However, over the past years there has been a significant improvement in the social perception of old age, which may be a period of development and The implementation of new tasks, adapted to the capabilities and seni needs ora, where attention is paid to processes and passiveness Unit activity. Most importantly, from childhood to shape the habits of active life, active ways of spending free time, which will promote the process of active aging (Perek-Białas, Worek 2005).

Nowdays, old age is perceived as culturally shaped and stage of life aging as a natural process of life (Hamilton, 2006). Such change has been made both by the social activity of the elderly themselves and by the way A series of activities for seniors promoting successful, active old age. The increasing social activity of older people and the high demands placed on them, The fact that old age has its rights and eliminates ograniczenia.Seniorzy increasingly feeling the power to direct their own development, the $p$ slaughter taking all sorts of initiatives charac activating sculpture.

Helena Radlińska already in I In the twentieth century, she wrote that old age is a modified profession, including education Work on yourself : In professions that require education and training Work on yourself-old age is delayed "(Radlińska 
1947). Polish Seniors. They are increasingly involved in social life, they care about the longest possible preservation of intellectual and physical skills, by participating in various forms of social activation. According to Aleksander Kamiński, author of the quote ,, add life to years and not years to life ", promoter of the theory of activity and education to old age, the key to a positive and satisfactory aging is to support seniors in expanding their interests, aspirations, skills and eliminating erroneous habits. The foundation of a healthy retirement is to accept their aging And try to organize yourself a satisfying, active life again.

In consideration of old age and aging, regardless of the scientific discipline and cultural factors, the category is commonly analyzed human activity. Usually Defined is she as Innate trend down actions, way Communicating with other people and the surrounding world. Theories of adaptation to old age assume it is a period that allows seniors to maintain the present, and even deepening activity in family, social and work sometimes, and improving the quality of life associated with his sense of feel iem (Steuden, 2010).

Although old age is a process that of Natural causes can not be stopped, its effects, especially the negative ones, can be reduced or slowed down their pace. All activities, especially taken with Their own will, they can provide a lot of joy, enrich health, improve the well-being and make people more confident. It is precisely by the activity of the old man can strengthen the meaning of life, strengthen satisfaction, and also change the quality of life.

Very often old age is associated with worsening health conditions, it can not always mean lack of life satisfaction. This means that positive aging is not just a "privilege" for healthy people. This attitude requires a certain discipline, and draws attention to the fact that the permanent grow together does not have to be sad. It mainly refers to Getting the right distance to own and to live (Hill 2009). Any type of activity that an elderly person enters is called in ko nkretnej to meet the needs or interests of implementation. It is important to fix it and continuous stimulation for activity to keep the desire for action. Senior citizens aware of the beneficial effects of their activity are more likely to work on themselves, as long as possible to maintain good physical condition and psychical. Many people realize that the longer they work on themselves, the later they will begin to feel the effects of old age. At the moment of cessation of these activities the individual notes that he is on the threshold of authentic, declining old age (Kamiński 1986).

One of the most commonly known methods of positive passage in Age is an activity. The human organism of nature is designed for activity. Its refusal may result in faster infirmity. A man leading active lifestyle signs of aging will feel later than his passive peers. Activity is a way of life positive. It affects communication with the public and the world.

\section{The forms of activity are divided into three groups:}

Formal appearing in participation and work for social associations, local community, volunteer activities, involvement in Politics, etc.

Informal, frequent contact with Family, friends, friends, neighbors, etc.

Loneliness - activity manifested by developing your own interests, giving up hobbies, passion, watching television, reading, solving crossword puzzles,

In addition to seniority are influenced by various factors that can decide on making activity retired or its omission (Szatur- Jaworska, Błędowski, Dzięgielewska 2006):

Education - people with Higher education is more aware of the positive relation of activity to life, therefore they more often take it;

Family environment - the family, its origin and intergenerational relations have a large impact on activity;

Condition and health - this condition is very important because better health and psychophysical efficiency facilitate activity;

Material conditions - depending on what kind of activity a senior can afford for financial reasons, eg travels, sanatorium, participation in Cultural events;

Sex - women far outnumber retirees so they are more likely to be active;

Place of residence (city, village) - offer addressed to seniors living in rural areas is definitely poorer; 
Influence of cultural institutions - if in There is a cultural institution in your area, which also directs your offer to seniors, then this age group is more likely to be interested in activity.

It is important to attach great importance to the preservation of active lifestyle, by continuing those forms of activity that have so far given so much satisfaction, and There was no time for such things as gardening, traveling, learning foreign languages. If this is not possible, focus on developing other new interests. Senior activity fulfills many important functions including:

- Adaptive - serves better adaptation to the new, ever-changing conditions of both the family and the situation Social;

- Integrative - helps in Adapting to a group of people in Similar age;

- Compensation - allows to compensate for deficiencies in Areas such as lack of professional work, etc .;

- Educating - leads to the development of acquired or acquired new dispositions;

- Entertainment - recreation - by filling free time, neutralizes stress and returns the desire to live;

- psychohigieniczna - keeping activity improves quality of life and increases the level of satisfaction;

This, in How can a person experience his or her old age? Individual personality conditioning but also with Adopted in A family lifestyle, cultivating the tradition. Active aging can be characterized by preference for their chosen lifestyles, such as (Czerniawska 2000):

Completely passive style - characterized by staying in Home and Limitation of family contacts and Social to a minimum. This type of behavior may result with illness or disability, where the barrier is the difficulty in Movement, but also other matter is the mental barrier, where the older man reluctant to use Of any form of activity, withdraws from Social life and It closes in Myself;

Family style - people who make this style feel fulfilled by playing the role of grandmother or grandfather helping children to raise grandchildren. This form of activity occupies the entire free space for the elders so that they no longer have time for another form of activity;

Style resulting from Possession of a parcel garden - people who have a parcel garden especially retired spend all their spare time nursing and plant the plants which brings them full satisfaction. They can This way of making new social contacts eg from Members of the Family Garden Gardeners and neighbors;

Style based on activity in Social association - this is a style implemented especially by older people who enjoy good health and are socially active and socially. Such persons are active in Various societies, associations, circles of interests, trade unions, political parties and operate in Volunteering. These people are rewarded for their work for others, for their help and for their social life;

Domocentric style - this is style with Borderline family and Completely passive. These people are accomplished by practicing their hobby (crossbreeding, flower breeding, etc.) but without going out Home They use the mass media and engage in Help the family;

Pious style - it is performed by religious people who use it Excess leisure time is focused on more active participation in Church life and numerous church movements

A different distribution of active aging due to the interest has G. Orzechowska (Orzechowska 1999), who distinguishes the following forms:

Home-based activity related to running a family home and the functioning of the immediate family

Cultural activity, which is predominantly manifested in the urban lifestyle: reading the press, watching television, participating in socio-cultural institutions

Occupational activity that satisfies the need for recognition, improves well-being, improves self-esteem 
Social activity means voluntary action for a specific group or local environment, eg: Increasingly popular volunteering among seniors

educational activity, which allows the extension of memory performance, mind, experience new information technologies and learning opportunities tailored to the interests of each senior eg .: Am squint to participate in UTA

Religious activity, which, with age, becomes significant

recreational activity, which sometimes is a substitute for a recent work, otherwise allows for communing with nature and requires a greater effort from fizyczneg

Increased activity contributes to improving a person's well-being, improving self-esteem, lowering anxiety, helping in acceptance of the last phase of life, a It also leads to increased frequency and Intensity of interpersonal contacts. Wide range of activities in every phase of development involves developing personality, increasing self-confidence, broadening the horizons of thought. These elements have an impact on building a positive self image, and in Consequences of better coping with any problems that arise in the life. Active person in crisis situation does not close in He himself, takes a stand ready to act into develop such an attitude play an important role such factors jak: personality type, health status, family situation, material, education, access to cultural institutions.

\section{Functions, types and forms of "free time"}

The term "free time" has appeared and disseminated relatively late, It was not until 1957 that it was recognized by the UNESCO International Commission (Matyjas 2003). There are currently many free time definitions. They accentuate its various aspects - sociological, psychological, pedagogical and physiological-health. It seems that one of the more comprehensive definition presents M.Kwilecka, where free time is: ,, sphere ... free, unhampered human activity, time spent on various activities providing leisure, entertainment, broadening knowledge and interests held, the development of creative abilities, and so A time when the feelings of coercion are minimal, the time of activity chosen according to our own reason, reason and willingness. Such free time is the sphere of human existence, where there are no direct obligations and normative constraints, ie autonomous time, discretionary, freely used by man according to his own tastes and possibilities, that is, time totally dependent on the individual, regardless of his Use The free time is related to shaping and improving life both in its social as well as individual form " (Kwilecka 2006). Human time in most cases is roughly divided equally in sleep, rest and work, and this rhythm is strongly linked to gender, age, and social position (Ciskszentmihalyi1997). What man remains in the day, after fulfilling all obligations connected with creative and productive activity and being free time. Today it is filled with three types of behavior:

- use of public communication

- lead the conversation

-course with a variety of activities ranging from hobbies, sports, to cinema, theater or restaurants (Ciskszentmihalyi1997). Such a division is convergent wyróżnianymi by researchers culture systems and refers to social life in the collective wości of local or broader (K łoskowska 19720.

With discussed $k$ Westie activity linked to the cap of the free time of the elderly. However, as Brunon Synak observes, the free time of old people is a difficult category to identify, because it is not easy to point out what their daily routine is to be voluntary and what is compulsory (Synak, 1982). Therefore, some scholars take the concept further, or the time półwolny seniors, that is, one: ,, which is designed for operations to duty, which is performed with the feeling that they should be performed, and at the same time combined with the awareness of voluntary and pleasure to perform actions' ( Zaorska 1987).

Undoubtedly, free time is the only sphere in a man's life in which he can freely and freely develop without the compulsion of any institution of social life. The lack of sense of duty, the freedom of choice, and his or her consciousness are the basis for determining which behaviors are free and which are not. Their choice is conditioned by the specific characteristics of man and his current situation. To participate fully in free time, a certain level of education (usually medium) and material status is required. The latter is important in that, in the absence of satisfying the needs, even understood only subjectively, free time is sold on the secondary labor market. Certain behavior in their free time are strongly correlated with the basic socio-demographic characteristics (sex, age, social position) participants of social life. Free time fully to man important 
functions, which, in principle, in equal measure must exist in the life of the individual. In doing so can lead to disturbances in the functioning of a man not only as a member of the community, but also as a biological organism. C performs the following curtains free functions (Wnuk-Lipinski 1972):

- an educational function involving the expansion of their skills and knowledge. Through personal development is met the need to explore the world and to develop Own skills

- switches the function will raise implemented by learning how to behave in a given situation, the assimilation of social norms and values

- integration function, which is connected with the strengthening of family ties, friends. The implementation of this function involves performing joint activities in a free time

- recreational function consisting in rest, both in the physical and mental dimensions of the individual

- a cultural function realized by the creation of cultural values

Compensation-function, which satisfies the needs of selected, including those mental spending leisure time and resting in a fun way is essential in every individual's life. The most obvious function of free time is rest, which can be active, doing something that brings peace and unloading of tension and passivity, which does not require physical involvement, for example: crocheting.

Forms of entertainment, which in youth were joyful, with age may already be unreachable, for example: sports. But an excess of free time, a feature that most seniors, allows for other reasonable and satisfactory development, eg . volunteering, travel, childminding, pilgrimage, prayer.

Increasingly popular form of seniority is participation in universities of the Third Age, Senior Clubs or volunteering. As noted Czerniawska: ,, aim of the Third Age University is not only improving the lives of the participants, but also a change for the better conditions of life of the elderly living in the community and in the world "(Czerniawska 2000). The overall aim is functioning UTA quality of life of older people. G hunted objective is to stimulateseniors conducted in the form of lectures, seminars, discussions, foreign languages language courses, sightseeing trips and recreation and rehabilitation (Steuden 2012).

Manlomd is not only a social being but also an active being by nature. This activity expresses needs, not only the basic biological but also Those second order, showing Come on between Others through The need Affiliation, Recognition, Cognitive, Prestige, respect, aesthetic experience or science. In the process of education, realized among other things through participation in the UTW, seniors have the opportunity to realize their own interests, to broaden their knowledge, to shape their personality and creativity, to develop their ability to work in Team, and also Skilful management sometimes free.

Next form of seniors activation is functioning and activity Clubs Senior. The main function of such activities tytucji ins for older people is to organize free time. Programs used in such institutions may be the reason used in other markings on a similar profile. In addition to spending leisure time, the purpose of this institution is to meet the needs of a higher order by fostering numerous social contacts, which promotes social bonding, prevents loneliness, boredom and emptiness. Club members have the opportunity to help each other, seek specialist advice. We could talk about fulfilling certain Features: Compensatory through Replenishment Contacts Social, Integrative that Community, psychotherapeutic, preventing aging and adaptation stress by adjusting to changes in living conditions (Lesczyńska-Rejchert 2010). Among the forms of social, cultural and physical activity are conducted various educational profiles, interest groups, hobbies, readings, lectures. Meetings with interesting people are organized, readers are encouraged and encouraged to amateur artistic activities. Popular is the common viewing of television that ends in a discussion. Various shows, social games, concert halls, cinemas, theaters are offered. Very popular dance evenings, trips, pilgrimages, and occasional meetings. Members associated in the Club not only actively participate in the proposed forms of activity but also have an impact on determining the curriculum and activities of the Club (Szatur- Jaworska, Błędowski, Dzięgielewska 2006).

Research conducted by the Center for Social Opinion Research in 2012 in the Ogonopolska trial shows that $65 \%$ of the respondents have as much free time as they need. $21 \%$ thought they had too much free time, and $14 \%$ have not enough (Omyłka-Rudzka 2012). Research on older people clearly indicates that seniority leisure is closely linked to Age and 
Generally, however, the area of interest of seniors is quite narrow. Rarely is the use of Engage in social or political activity. This is confirmed by the SHARE study, conducted by the Institute for Educational Research, with which shows that the current level of total rności in the last 12 months showed $22 \%$ of respondents, about $30 \%$ of the indicated activity as reading books and Newspapers, secondly, is participation in religious practices. Relatives spend a lot of time watching television $(40 \%)$, including newspapers. In addition study shows that activity in all analyzed areas decreases with age, except for great religious ktyki (Holzer-Żelażewska, M aliszewska, Paczyński 2014). The presented test results are consistent with research of the European Commission, which in the age group 55+ are the most popular form of activity actions in religious organization, church, charity or dealing with social (Bojanowska 2016).

\section{Summary}

Into a free time definition we could implement a whole range of human needs: aesthetic, cognitive, emocjalnych, twórczych.Niebagatelne importance in the spending it also has a social aspect, the Community, because it satisfies the need for affiliation, or belonging to different social groups, and the need for acceptance ws pressure. Basic, which need universal, common to all human beings, affect the development of both individual physical, intellectual, emotional, and social and spiritual. As time goes by, human needs change as well as the power and capacity to meet them.

Nowdays demographic trends indicate that we will be increasingly aging population, the all the circumstances relating to the changes in in daily life. It becomes necessary to undertake a wide range of activities aimed at changing the image of the elderly and and old age phenomena. Increase in the number of older people regardless of their age and social, economic an political potencial people age should cause to seek ways of rengthening and activating (empowerment) of the game ups abrogated thus depend on nannies from social assistance through the wider activation of older people in environment, mainly in the local perspective.

\section{References:}

[1] B. Szatur- Jaworska, P. Błędowski, M. Dzięgielewska, Podstawy gerontologii społecznej, Warszawa 2006.

[2] Błaszczuk K., Rynkowska D., Problemy społeczne i opiekuńcze seniorów i ich rodzin, Rzeszów 2016.

[3] Błaszczuk K., Rynkowska D., Wybrane problemy zdrowia publicznego w perspektywie pracy socjalnej, Rzeszów 2014.

[4] Bojanowska E., Potrzeba aktywności osób starszych oraz formy jej realizacji, [w:] Etyka-RodzinaSpołeczeństwo,Tom I, ( red.) G.Grzybek, Z.Chodkowski, J.Meissner-Łozińska, Rzeszów 2016.

[5] Ciskszentmihalyi M., Urok codzienności, Warszawa 1987.

[6] Czerniawska O., Drogi i bezdroża andragogiki i gerontologii, Łódź 2000.

[7] Flora P., Noll h.H., Sozialberichterstattung und Sozialstaatsboebachtung, Frankffurt/Main 1999.

[8] Hamilton I.S., Psychologia starzenia się, Poznań 2006.

[9] Hill R.D., Pozytywne starzenie się. Młodzi duchem w jesieni życia, Warszawa 2009.

[10] Holzer-Żelażewska D., Maliszewska A., Paczyński W., Aktywność społeczna i edukacyjna 55+ [w:]Portret generacji 50+w Polsce i w Europie.Wyniki badania zdrowia, starzenia się i przechodzenia na emeryturę w Europie (SHARE), (red.)A.Chłoń-Domińczak. IBE, Warszawa 2014.

[11] Kamiński, Aktywność jako wzmaganie żywotności osób starszych [w:] Encyklopedia seniora, I. Borsowa (red.), Warszawa 1986, s. 117.

[12] Kwilecka M.(red.), Bezpośrednie funkcje rekreacji, Warszawa 2006.

[13] Leszczyńska-Rejchert A., Człowiek starszy i jego wspomaganie- w stronę pedagogiki starości, Olsztyn 2010

[14] Matyjas B., Czas wolny, [w;] Encyklopedia pedagogiczna XXI wieku, T.Pilch (red.), Warszawa 2003. 
[15] Omyłka-Rudzka M., Sposoby spędzania czasu na emeryturze. Komunikat z badań nr4689 CBOS, Warszawa 2012.

[16] Orzechowska G., Aktualne problemy gerontologii społecznej, Olsztyn 1999.

[17] Perek-Białas J., Worek A.(red.) Aktywne starzenie się. Aktywna starość, Kraków 2005.

[18] Radlińska H., Oświata dorosłych.Zagadnienia.Dzieje.Formy.Pracownicy.Organizacja,Ludowy Instytut Oświaty i Kultury, Warszawa 1947.

[19] S.Steuden, Psychologia starzenia się i starości, Warszawa 2012.

[20] Synak B., Migracja i adaptacja ludzi starszych do środowiska miejskiego, Wyd.UG, Gdańsk 1982.

[21] Wnuk-Lipiński E., Praca i wypoczynek w budżecie czasu, wyd.Ossolineum, Wrocław 1972

[22] Zaorska A., Aktywność kulturalna ludzi starszych, Wyd.UMCS, Lublin 1987. 